\title{
MEDICAL PLANTS IN DIFFERENT SOILS WITH HEAVY METALS
}

\author{
Laura Binxhija ${ }^{1^{*}}$, Arjana Ylli ${ }^{1}$

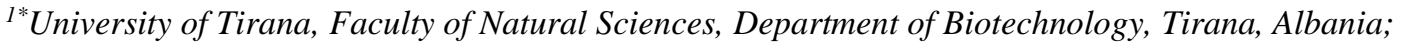 \\ *Corresponding Author Laura Binxhija, e-mail: laurabinxhija@yahoo.com;
}

Received March 2021; Accepted April 2021; Published June 2021;

DOI: https://doi.org/10.31407/ijees11.320

\begin{abstract}
The goal of this study is to determine and evaluate environmental indicators and pollution presence in various regions of Kosovo. Juniperus communis L. and Juniperus oxycedrus L. are medical plants, useful for their therapeutic aspect. The large pollution generated in thermal electric plant, Obiliq, and from other industrial processes in the region of Mitrovica have resulted to have contaminated soil, water and plants with heavy metals over the permissible norms. Such contamination presents a permanent risk to the environment as a result of uncontrolled releases into river waters and in the lands nearby industrial zones. Juniperus oxycedrus L. samples have been taken in Vllahi - Shala e Bajgorës, close to mines and foundry, on the outskirts of Trepça, and have also been collected Mushtisht - Therandë. The sample of Juniperus communis L have been collected in Sllatinë - Fushë Kosovë, near Obiliq, and also have been collected in Novobërd - Artanë and Bajgore - Trepçe. We intend to evaluate the content of heavy metal elements like $\mathrm{Cd}, \mathrm{Cu}, \mathrm{Fe}, \mathrm{Ni}, \mathrm{Pb}$ and $\mathrm{Zn}$ using ICP-OES technique (EPA method 6010C:2007). In all five study areas it was noticed that the soils had high levels of iron, lead, nickel and zink, which in most cases was observed also in leaves and berries.
\end{abstract}

Key words: Juniperus communis L., Juniperus oxycedrus L., heavy metal, contamination. 